Volume 2

Number 2 Teaching Secrecy

Article 5

January 2021

\title{
Teaching Trade Secret Management with Threshold Concepts
}

\author{
Haakon Thue Lie \\ Norwegian University of Science and Technology, htl@leogriff.com \\ Leif Martin Hokstad \\ Norwegian University of Science and Technology, leif.hokstad@ntnu.no \\ Donal O'Connell \\ Imperial College Business School, donal@chawtoninnovationservices.co.uk
}

Follow this and additional works at: https://scholarworks.sjsu.edu/secrecyandsociety

Part of the Business Administration, Management, and Operations Commons, Educational Methods Commons, Legal Education Commons, Science and Technology Studies Commons, and the Technology and Innovation Commons

\section{Recommended Citation}

Lie, Haakon Thue; Leif Martin Hokstad; and Donal O'Connell. 2021. "Teaching Trade Secret Management with Threshold Concepts." Secrecy and Society 2(2). https://doi.org/ 10.31979/2377-6188.2021.020205 https://scholarworks.sjsu.edu/secrecyandsociety/vol2/ iss $2 / 5$

This Special Issue Article is brought to you for free and open access by the School of Information at SJSU ScholarWorks. It has been accepted for inclusion in Secrecy and Society by an authorized administrator of SJSU ScholarWorks. For more information, please contact scholarworks@sjsu.edu.

\section{(c) $(1) \ominus$}

This work is licensed under a Creative Commons Attribution-Noncommercial-Share Alike 4.0 License. 


\title{
Teaching Trade Secret Management with Threshold Concepts
}

\author{
Abstract \\ Trade secret management (TSM is an emerging field of research. Teaching trade secret \\ management requires the inclusion of several challenging topics, such as how firms use \\ secrets in open innovation and collaboration. The threshold concepts framework is an \\ educational lens well suited for teaching subjects such as TSM that are transformative and \\ troublesome. We identify four such areas in trade secret management and discuss how \\ threshold concepts can be a useful framework for teaching. We then present an outline of a \\ curriculum suited for master's programs and training of intellectual property (IP) \\ managers. Our main contribution is to fields of management and educational sciences, as \\ well as those of innovation studies and jurisprudence.
}

\section{Keywords}

appropriation mechanisms, educational methods, intellectual property management, secrecy, secrecy studies, threshold concepts, trade secret management, trade secrets 


\title{
Teaching Trade Secret Management with Threshold Concepts
}

\author{
Haakon Thue Lie, ${ }^{1}$ Leif Martin Hokstad, ${ }^{2}$ and Donal $\mathrm{O}^{\prime}$ Connell ${ }^{3}$
}

\begin{abstract}
Trade secret management (TSM) is an emerging field of research. Teaching trade secret management requires the inclusion of several challenging topics, such as how firms use secrets in open innovation and collaboration. The threshold concepts framework is an educational lens well suited for teaching subjects such as TSM that are transformative and troublesome. We identify four such areas in trade secret management and discuss how threshold concepts can be a useful framework for teaching. We then present an outline of a curriculum suited for master's programs and training of intellectual property (IP) managers. Our main contribution is to fields of management and educational sciences, as well as those of innovation studies and jurisprudence.
\end{abstract}

\section{Keywords}

appropriation mechanisms, educational methods, intellectual property management, secrecy, secrecy studies, threshold concepts, trade secret management, trade secrets

1 Associate Professor, Norwegian University of Science and Technology, https://www.ntnu.edu/employees/haakon.thue.lie

2 Professor, Norwegian University of Science and Technology, https://www.ntnu.edu/employees/leif.hokstad

3 Chawton Innovation Services Ltd., http://www.chawtoninnovationservices.co.uk/Biography.html 
Trade secrets are secrets with commercial value that are also suited for trade. As a concept, "trade secrets" has both a legal definition depending on the particular jurisdiction - and a managerial one. The use of "trade" implies that the secrets in question can be shared with others. To be shared in a commercial setting, such as for licensing or as part of open innovation, a secret must be defined, delimited, and managed. In this case, management includes keeping track of those "in the know" and taking measures to control access to the secret information. Trade secrets may concern technology, business strategy, customer data, or any other intentionally concealed information of value to a business. Thus, trade secrets are of interest to both the general management of businesses and those who engage in innovation. Secrecy is a broader term that also encompasses trade secrecy, as well as secrecy that protects privacy and national security. A trade secret could thus belong to more categories of secrecy. In open innovation and research collaboration, participants may be - aside from firms - universities, research institutes, hospitals, and public bodies. There are many bodies who could benefit from learning about the management of trade secrets; however, there is a lack of a theory and framework for teaching on this topic.

Maret (2016) problematizes secrecy and frames it as "a compelling social problem." Secrecy connected to violations of human rights is one example of secrecy as a social problem; unethical business is another 
example. Claiming that information as a trade secret can be an excuse for hiding crimes or unethical business behavior, such as tax evasion, as revealed in the Panama Papers (Abazi 2016). We frame trade secrets as an option for organizations to create and secure competitive advantages for the benefit of business or society.

However, ethical challenges associated with trade secrets are easily understood by students and are not challenging to teach. In this article, we discuss other aspects of trade secrets and their management that are challenging to teach, such as the paradox of "secrets" used in "open" innovation. We present an educational framework, "threshold concepts," that addresses these aspects. Our article is conceptual and explorative, from the standpoint of educational sciences and the teaching of IP concepts in management and innovation studies; our research goal is to substantiate threshold concepts as a framework for teaching trade secret management and to exemplify this framework with a curriculum outline.

The following sections of this article provide background and context on the subject of trade secrets. We then discuss how they are managed. We explain the term "simultaneities" as it relates to trade secrets and their counterintuitive and troublesome nature, then propose a list of challenging issues with regard to teaching trade secret management. Along the way, we provide examples and identify possible threshold concepts. We then apply these threshold concepts to outline a curriculum on trade secrets in the 
context of a typical intellectual property (IP) management course. We conclude with recommendations for further research.

\section{Background and Context: New Legislation and Teaching Challenges}

Trade secrets are often used together with other mechanisms, such as patents and copyright, to control innovation. Trade secret management can thus be viewed as an integral part of IP management. There is currently limited research on trade secret management and, to our knowledge, no research on how to teach it. ${ }^{1}$

Recently, both the EU and the USA amended their legal framework for trade secrets. The new laws are more precise than previous ones as to their scope and the types of secrets they regulate. These legal changes concern how trade secrets can be objects for licensing and knowledge sharing as functions of collaboration and open innovation. When we teach how to manage trade secrets, this contrast between secrecy and openness is paradoxical or counterintuitive. ${ }^{2}$

$1 \quad$ Evans (2012) presents an interesting case study on trade secrets in the teaching of law. The case concerns trade secret management; however, its scope is that of trade secret law and the practical application of American jurisprudence.

2 In English, that paradox is embedded in the term itself, as the words imply some secret exchange of knowledge - or at least that the secret concerns something that is transferred. However, this is not the case in other languages. As examples, in German and Scandinavian languages, "trade secret" is equivalent to "business secret" (Betriebs- und Geschäftsgeheimnisses, forretningshemmelighet, bedriftshemmelighet). In French, "industrial secret," "commercial secret," or "business secret" (secret industriel, secret commercial, secret des affaires) "commerce" implies sharing. Similar etymological differences seem to exist among other languages. 
Teaching trade secret management builds on learners having prior understanding of concepts of intellectual property and its management at an advanced level. National laws and traditions regarding trade secrets are complex and differ among jurisdictions; however, those differences mostly affect how to manage possible misappropriation. Thus, from a teaching perspective, understanding in detail jurisdictional differences among the USA, the EU, China, Japan, or any other country or state has little relevance to the topic of trade secret management within these countries' organizations; it is enough to know that there are legal differences. As innovation and trade are often international, a manager of trade secrets has to know when to call on international legal expertise. The authors of this article are all Europeans and none are lawyers. Our perspective is that of managing trade secrets within organizations that collaborate with others, often across jurisdictions or cultures.

\section{Introducing Threshold Concepts}

Our experience in teaching trade secret management stems from teaching students at master's programs at European universities, experiences in course design in higher education, as well as courses for IP managers and other managers of innovation in research, development, and business operations. For all these groups, we have noticed that some curriculum topics require special attention because they are not only 
complicated and challenging, but also counterintuitive. Taking this initial realization as a starting point, the educational principles of the threshold concepts framework could be useful in teaching the topic of trade secrets (Flanagan 2020). This framework could provide a way to understand the characteristics and nature of trade secrets and their management, and to shed light on the consequences of this understanding for teaching the subject of trade secrets and trade secrets management.

The threshold concept framework is a pedagogical framework that focuses on aspects of a field or discipline that at face value seem counterintuitive and troublesome, yet understanding these aspects is essential to understanding and mastering that field or discipline. These aspects or concepts in the discipline may be seen as a portal; passing through it leads to a transformed understanding of the subject matter and a reformulation of the learner's frame of meaning. This implies an ontological change in the learner, a new way of seeing things (Meyer and Land 2003, 2005, 2006; Land et al. 2005).

Early research in the field stems from economics, where, for example, an underlying barrier to students' understanding were linked to the concept of "opportunity cost." This barrier was seen as one such essential threshold into the understanding of economic theory (Shanahan and Meyer 2006). In this research, the focus was upon identifying and describing an educational 
core or points of gravitation in a field, to contribute to an integrated understanding of the field.

Using this background and context, we review challenging and complicated issues in trade secrets management teaching to determine whether they can be viewed as counterintuitive. We use characteristics of counterintuition as an indicator and point of entry into a challenging topic, because while teaching, we have observed students' confusion and lack of understanding. Thus, the method we employ to address these perceived problems is to develop discussions of these counterintuitive issues and compare them with the characteristics of threshold concepts.

Table 1 illustrates possible characteristics of a threshold concept. Together, these characteristics describe the highly complex nature of a threshold concept.

Characteristics

Transformative

Troublesome

Irreversible

Integrative

Bounded

Discursive

Reconstitutive

\section{Comment}

Changes the way in which the student views the discipline.

For example, counterintuitive, alien, or seemingly incoherent.

Difficult to unlearn.

Combines different aspects of the subject that the learner had not previously seen as related.

Delineates a particular conceptual space, serving a specific and limited purpose.

Incorporates enhanced and extended use of language.

May entail a shift in learner subjectivity, which is implied through the transformative and 
Liminality

discursive aspects already noted. Such reconstitution is, perhaps, more likely to be recognized initially by others, and also to take place over time.

Threshold concept mastery often involves "messy journeys back, forth, and across conceptual terrain" (Cousin 2006, 5).

Table 1. Characteristics of threshold concepts, adapted from Flanagan (2019).

The threshold concepts framework is increasingly applied as a point of reference for teaching challenging issues; there are a growing number of empirical studies. Threshold concepts are now considered among highimpact pedagogies (Nicola-Richmond et al. 2018). The challenges in teaching trade secret management stem from the nature of secrecy as complicated and human. Bok (1989) discusses how control over secrecy and openness is needed to protect a person's identity, plans, actions, and property. That need for protection is similar to that of a firm or an organization, for which trade secrets are a common form of secrecy.

\section{Trade Secrets in Management Science and Jurisprudence}

Innovation and management researchers see trade secrets as an innovation appropriation mechanism that is used jointly with other mechanisms such as patents, copyright, trademarks, as well as standardization, certifications, and other means of controlling and capturing value from innovation. Beginning in the $1980 \mathrm{~s}$, research on innovation 
included secrecy as a way to appropriate innovation (Levin et al. 1987; Von Hippel 1982). For example, Nonaka and Teece (2001) discussed trade secrets in the context of managing industrial knowledge, including examples of managerial practice in American firms; Hemphill (2004) described the strategic management of trade secrets as influenced by legal, organizational, and market environments. Working over three decades, David Teece has included trade secrets in IP management research, and from that has studied the topic in the area of strategic decision making (Teece 2018, 1986). For the past decade, David R. Hannah has researched how rules on trade secrets associate with management and procedures in a firm (Hannah 2005, Hannah et al. 2019).

In most jurisdictions, trade secrets are regulated by national legislation, but they are included in a broad web of mechanisms in trade and knowledge exchange. Regulations concerning trade secrets and fair competition are, for example, part of trade agreements and international conventions from the last century. Sandeen (2018) discusses the historical connections between the new US and EU laws on trade secrets and wrongful acquisition of information in terms of the delicate balance between information protection and diffusion from laws on patents, copyright, unfair competition, and trade secrets. The rewards of innovation from the open flow of information may be greater than what society can gain from 
Secrecy and Society, Vol. 2, No. 2 [2021], Art. 5

introducing new, property-like rights for information that is not already regulated. ${ }^{3}$

In jurisprudence, there has been a century-long debate on how best to regulate trade secrets. They could be seen as any combination of intellectual property, breach of confidence, and unfair competition (Lemley 2008). ${ }^{4}$ That discussion is outside the scope of this article but illustrates that the teaching of trade secret management should include several perspectives. ${ }^{5}$ The view that people regard secrets as property is, however, part of the foundation of secrecy studies.

Aside from aside from agreements or contracts, to explain this aspect of property as fundamental to trade secrets, a general definition of secrecy adapted from Simmel (1906) is instructive: "the intentional or unintentional concealment of information." Within Simmel's context and example of

3 There is also the question of national security and trade secrets. The lines between trade secrets, national security, and trade wars are blurry (Rowe 2016; Burgess and Power 2011) and with a long history. For example, were trade secrets an important part of the regulations of transatlantic trade in the sixteenth century (Vermeir and Margócsy 2012). A recent example in media is the court proceedings against Huawei; see https://web.archive.org/web/20200215143825/https://www.cnbc.com/2020/02/14/huaweisays-us-charges-are-an-attempt-to-irrevocably-damage-its-image.html

4 The Paris Convention is the oldest international agreement on IP, originally from 1884. In 1900, a revision introduces article 10 bis on unfair competition. Trade secret misappropriation has always been regarded as one such form of unfair competition. Others include passing-off and counterfeiting. Later trade agreements, including the Trade-Related Aspects of Intellectual Property Rights (TRIPs), are more detailed with respect to trade secrets.

5 A manager needs to understand these different perspectives - as well as the regulations in different jurisdictions-as they can have implications for the legal measures available in the case of trade secrets misappropriation. Each perspective has some impact on the management of trade secrets, as documentation of the secret should follow legal practise for all relevant jurisdictions. We discuss later in this article the term "simultaneities": how seemingly different concepts may coexist as parts of the same phenomenon. 
marriage, in which "the secret of the one party is to a certain extent recognized by the other, and the intentionally or unintentionally concealed is intentionally or unintentionally respected" (Simmel 1906, 462), this definition is useful. As this article concerns trade secrets, information is intentionally or unintentionally concealed, collaborators know there are secrets, and they respect the concealment of those secrets. If concealment is not respected, then there is misappropriation or theft of the secret. This respect or trust is, together with the property view of secrets, essential.

\section{Trade Secrets and IP Management}

The term "trade secret" has a clear legal definition in the EU and the USA (Schultz and Lippoldt 2018). As we discuss later, trade secrets are more of a process than just being a commercial opposite of openness. Vague terms that include the explanatory (e.g., "undisclosed" or "proprietary") and the broad (e.g., "information" or "know-how") serve a purpose, in that they encompass information that may or may not become trade secrets as well as the legally well-defined trade secret. "Secret" itself has negative connotations (Bok 1989, 12). For a researcher that needs to keep a trade secret, it can be better to talk about "proprietary technology" and thus avoid a conflict with the Mertonian norm of communality. For a business manager or lawyer drafting a nondisclosure agreement, "confidential business information" may appear more relevant. 
Most legal definitions of "trade secret" include four concepts for knowledge to be considered a trade secret: (a) it is business-related technical or commercial information, (b) it must not be known to the public, (c) its secrecy must have business value, and (d) there must be a reasonable effort to protect it against disclosure.

It is an integral part of the teaching of trade secrecy to explain and discuss the impact that different terms and jurisdictions have on its practical management. Doing so is complicated but not challenging, and is clearly defined: different national legislation all incorporate variants of the Paris Convention's more than hundred-years-old rules on the principle of unfair competition (Bodenhausen 1968). ${ }^{6}$

\section{Exceptions from Trade Secret Legislation}

There are areas in which secret information is not protected by trade secret laws. An important issue in teaching is to explain and discuss these exceptions in the context of ethics and societal needs. Our examples are from the EU directive (European Commission 2016). As the directive is new, it is unclear how broadly it will apply to the public interest. Whistleblowers are, for example, protected under US laws (Levine and Seaman 2018;

6 The Paris Convention (1884) is the oldest international agreement on IP. In 1900, a revision introduced article 10 bis on unfair competition. Trade secret misappropriation has always been regarded as one such form of unfair competition. Others include passing-off and counterfeiting. Later trade agreements, including the Trade-Related Aspects of Intellectual Property Rights (TRIPs) are more detailed with regard to trade secrets. 
Menell 2017) and in many other countries (Right2INFO.org 2019). Some examples from the EU follow:

Investigative journalism: Journalists in the EU cannot be hindered by trade secrets legislation to investigate and publish news on companies' practices and business affairs. The EU directive only concerns unlawful conduct by which someone acquires or discloses, without authorization and through illicit means, information with commercial value.

Legal obligations to disclose information of public interest: The EU directive does not alter the legal obligations on companies to disclose information for such public policy objectives. For example, in the chemical and pharmaceutical sectors, companies are subject to legal obligations to disclose information of public interest. The EU directive does not provide any grounds for companies to hide information that they are obliged to submit to regulatory authorities or to the public The rights of citizens to access documents in the possession of public authorities: Moreover, the EU directive does not alter and does not have any impact on the regulations that foresee the right of citizens to access documents in the possession of public authorities. Revealing misconduct, wrongdoing, or illegal activity: In addition, the EU directive expressly safeguards those who, acting in the public interest, disclose a trade secret for the purpose of revealing a misconduct, wrongdoing, or illegal activity. This safeguard is operative if the trade secret was acquired or passed to the whistleblower using illicit means such as the breach 
of law or contract. Abazi (2016) discusses how the EU directive increases the susceptibility of whistleblowers because of the burden of proof and the problems of demonstrating a general public interest. However, these problems also arise from the EU not having general legislation for whistleblower protection, only rules for specific sectors, in addition to laws in member states.

In the case of an organization, its management must understand when the information they wish to keep secret can be considered a trade secret. If employees are informed that trade secrecy applies to that particular information, and ethical considerations might subsequently lead to publication, then the ability to identify, keep, and manage the real trade secrets may suffer.

\section{Trade Secret Management}

Trade secrets may be viewed as secrets that have a causal relationship to a firm's competitive advantages. Business managers find that trade secrets are more important for controlling innovation than are patents, copyright, and trademarks. This view is confirmed by studies spanning the last thirty years from both the USA and Europe, as well as those of different industries and firm sizes contract or trust. For other IP, such as patents and copyright, jurisprudence defines the concept; there are no patents without patent law. For trade secrets, however, the laws are mere fallbacks in the case of unsuccessful management in addition to a framework for sharing. 
What matters is how managers of trade secrets teach and train their organization to keep those secrets, how the secrets are used for sharing knowledge within an organization and with third parties, and how the secrets are combined with other measures, such as patents and copyright, to create and maintain competitive advantages. In this view, the difference between secrets in general and trade secrets specifically is simply that trade secrets are managed with a commercial purpose (Levin et al. 1987; Cohen, Nelson, and Walsh 2000; Arundel 2001; Leiponen and Byma 2009; Gallié and Legros 2012; Hall et al. 2014; Eurostat 2016). Laws constitute a framework for knowledge transfer, such as licensing, in the form of trade secrets. This framework may be of use to the holder of a trade secret in the case of misappropriation if the secret is stolen or becomes public by breach of contract.

Large organizations may organize trade secret management as part of IP management. In other organizations, the management of trade secrets may be part of roles such as innovation managers or R\&D managers, integrated into legal or human resources management, or termed "knowledge management." Another important role is that of managing information security, or cybersecurity. The management tasks can be divided into phases, such as defining the trade secret, installing measures to protect it, exploiting it, and losing it (Granstrand 2000, 26; Lezzi, Lazoi, and 
Corallo 2018; Holgersson and Wallin 2017; Al-Aali and Teece 2013; Li and Tsai 2009; Bos, Broekhuizen, and de Faria 2015).

Secrets are a normal part of organizational knowledge management. Whenever they provide competitive advantages, the organizations tend to build procedures and rules for knowledge management. The procedures and rules are initiated either by management or by the employees themselves. Employees will be burdened with keeping secrets and may bend those rules rather than break them by adapting to situations not adequately addressed by the rules (Costas and Grey 2014; Grey and Costas 2016; Marx and Muschert 2009; Robertson, Hannah, and Lautsch 2015; Hannah and Robertson 2015; Hannah et al. 2019). Trade secrets are often used in combination with other mechanisms for controlling competitive advantages in innovation. To encompass both IP, including trade secrets and other mechanisms such as contractual agreements, researchers in innovation studies use "appropriation mechanisms" as a general term (Gallié and Legros 2012; Hall et al. 2014). The complexity of trade secrets being an organizational phenomenon, and being combined with other mechanisms, creates a need for a different approach to teaching than to IP management in general. We now turn briefly to complexity theory to explain how we use counterintuition as an indicator for topics that are challenging to teach.

\section{Simultaneities in Teaching Trade Secret Management}


Brent Davis (2008) describes "simultaneity" as "events and phenomena that exist or operate at the same time" (51). Simultaneities, derived from complexity theory and applied in education, oppose the ideas of binaries, dichotomies, and hierarchies, and form the basis for understanding counterintuition. Simultaneities are perceived by learners as counterintuitive and phenomena that are seemingly individual are presented both as a unity and as co-occurring. An example of simultaneity is the "knower and knowledge," where the curriculum reflects the knowledge and pedagogy reflects the knower. They coincide - interdependent yet independent - but remain separate. In trade secrets management, simultaneities exist on a fundamental level, in that openness and secrecy can be viewed as characteristics of the same information. ${ }^{7}$

Hilgartner (2012) discusses a "dialectic of revelation and concealment through which knowledge is selectively made available and unavailable to others, often in the same act" (268). In a historical example from the Human Genome Projects, researchers from competing organizations discuss trade secrets and future research directions during conferences. They intricately balanced openness and secrecy with "partial transfers of knowledge, targeted distribution, matters of timing, and the rights and

$7 \quad$ The debate in jurisprudence over whether trade secrets can be considered property may be viewed as a debate over a simultaneity. 
encumbrances that attach to knowledge at different points in its transit" (268). Complex information is simultaneously both open and secret.

We illustrate another practical simultaneity in Figure 1.

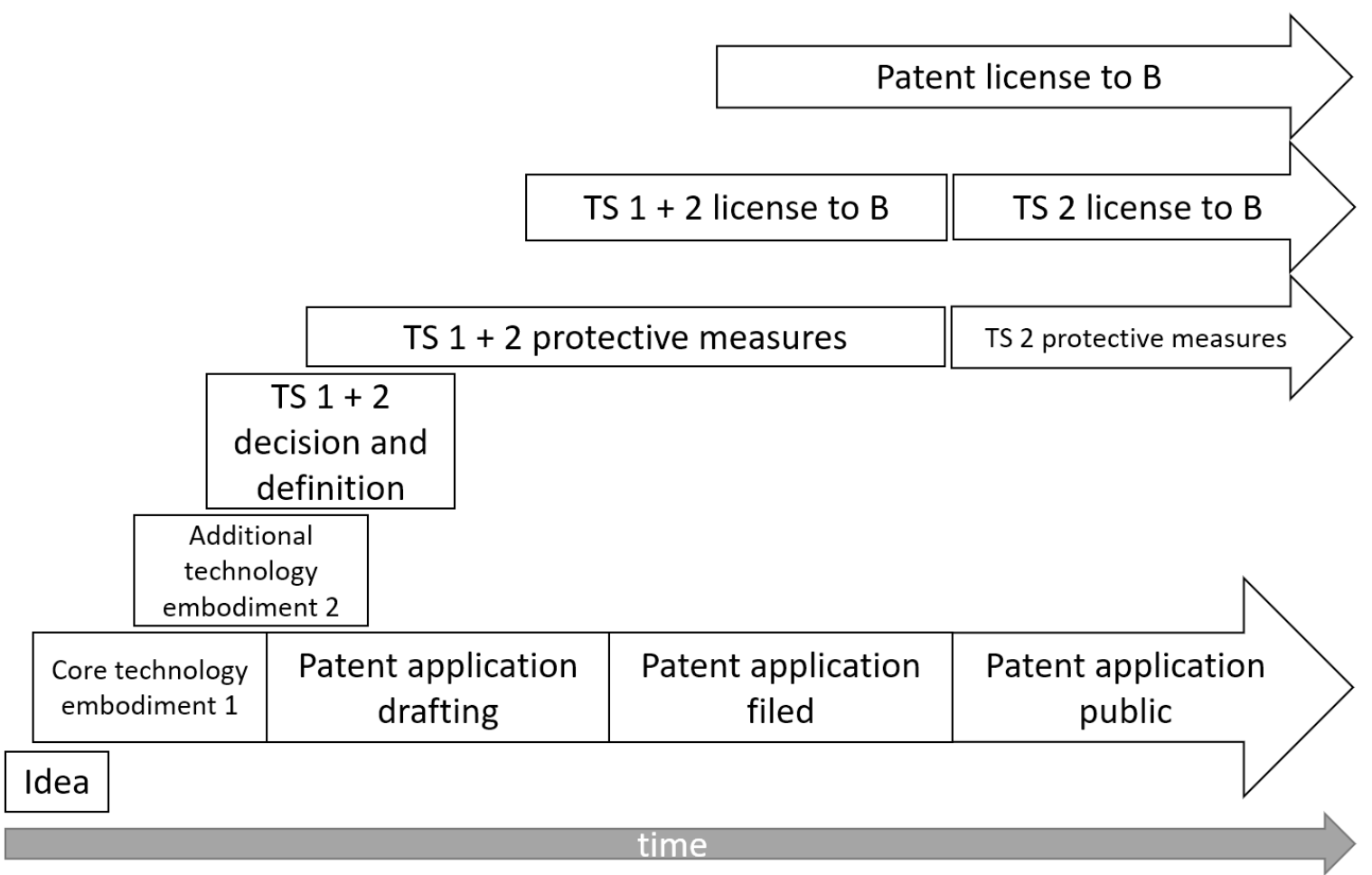

Figure 1. Combinations of trade secrets and patents - it is not either-or. For clarity, copyright and trademark use is not shown.

Here an idea is implemented into technology: the technology has a crucial part, a core, that we label "1." The firm then files a patent application. The technology is developed, and while drafting of the patent application begins, the firm understands there are other aspects of the technology that may be kept secret over time, labeled " 2 " in the figure. The firm now describes 1 and 2 and keeps them as trade secrets (TS). When 
they have done so and put protective measures in place, there are two trade secrets. TS 1 is what the later patent application describes; TS 2 is a useful addition, such as the temperature range in which a process is most efficient. There could be more additions of commercial trade secrets, such as the results from market tests or business plans, as well as trademarks, copyrights, and other appropriation mechanisms not shown in the figure. Now, firm B acquires a license; TS 1 and TS 2 are then both used. Meanwhile, the firm files a patent application that includes TS 1. Firm B acquires a license for the possible patent as well. The patent application is eventually published. As a result, TS 1 is no longer a secret and its use ends. However, TS 2 is now used as part of the license to firm B.

In this case, we use boxes to illustrate TS 1, TS 2 , the patent application, the granted patent, and the three licenses as different concepts. However, for educational purposes these can be presented as a simultaneity. It is hindsight to present the complete picture as we do. For the IP manager, the versions of the secrets and patent applications evolve together, but we have the luxury of separating them. Different people, organizations, and managers will be involved throughout the timeline, but at any one point, trade secrets, patent applications and patents will blend; there is no dichotomy.

\section{Experience-Based Issues That are Challenging to Teach}


We made a list of trade secret-related issues that we find challenging to teach, both at universities and in workshops with professionals, such as IP managers, chief technology officers, or corporate lawyers. For some issues, the challenges are complicated rules, differing legal systems, or arbitrary logic. However, we also realized that for some issues the challenge is their counterintuition. As an example, there is an inherent paradox in the fact that secrets can be used to share knowledge. As private individuals, we have all shared secrets; in this case, the context is itself the secret and is thus a personal matter. However, the border between secrecy, privacy issues, and trade secrets blend. One example concerns how clinical data from genetic testing are included in proprietary databases; in other words, the unique DNA of a person becomes part of a firm's trade secrets. This information can then be shared between firms (Cook-Deegan et al. 2012). Ethical controversies and a sequence of transactions create a counterintuitive situation. In the context of innovation or research, secrecy is often regarded as limiting the flow of knowledge, not as an enabler of sharing. Even in the clear case of the licensing of technology that includes trade secrets, knowledge sharing is not discussed beyond the agreed nondisclosure. In economics, "spillover effects" are recognized, but then often as a case of misappropriation of trade secrets due to workforce mobility (Delerue and Lejeune 2010). The fact that trade secrets solve the Arrow information 
Lie et al.: Teaching Trade Secret Management with Threshold Concepts

paradox,${ }^{8}$ as do patents, and are included in the paradox of openness, ${ }^{9}$

illustrates how the use of secrets is counterintuitive in that they form two paradoxes concerning innovation (Laursen and Salter 2014; Bogers 2011; Arrow 1962).

We propose a two-step process: first, to identify counterintuitive issues, and second, from these issues, to identify possible threshold concepts. Methodologically, we draw upon the process of identifying such bottleneck elements in learning material on the decoding-the-disciplines approach and "backcasting" (Robinson 2003; Middendorf and Pace 2004; Shopkow 2010). ${ }^{10}$

In Table 2, we list a selection of challenging issues and indicate possible counterintuition (the column marked $\mathrm{CI}$ ) to initiate mapping of the terrain. The examples discuss the distinction between complicated and counterintuitive issues. We chose counterintuitive issues as a point of entry to initiate further analysis, as these issues are - in our experience - most

8 Arrow (1962) shows how the prospective buyer of a technology wants to know how it works before paying. If the buyer then learns the technology, then they do not need to pay for the knowledge they've just received. If the seller has a patent, or there is legislation on trade secret misappropriation, then the paradox is mediated.

9 Laursen and Salter (2014) paraphrases Arrow in that "the creation of innovations often requires openness, but the commercialization of innovations requires protection" (867). Such protection can include trade secrets.

10 "Backcasting" is the colloquial opposite of forecasting: It seeks to design a desirable future, and then find policies and programs that connect to the present. See also the brief discussion on curriculum later in this article. 
challenging to teach. In Table 1, we present the characteristics of threshold concepts, and we compare these to the counterintuitive issues in Table 3.

\begin{tabular}{|c|c|c|c|}
\hline ISSUES & CI & COMMENTS, EXAMPLES & REFERENCE \\
\hline $\begin{array}{l}\text { Patent applications } \\
\text { may be kept secret } \\
\text { for } 18 \text { months, and } \\
\text { there are complicated } \\
\text { rules. }\end{array}$ & No & $\begin{array}{l}\text { Patent applications follow } \\
\text { national, regional, and } \\
\text { WIPO rules. The United } \\
\text { States allows publication by } \\
\text { inventor one year before } \\
\text { application, and secrecy for } \\
\text { national-only applications } \\
\text { until granted. After } 18 \\
\text { months, the application and } \\
\text { all prosecution are public. } \\
\text { The } 18 \text { months is regarded } \\
\text { as practical and builds on } \\
\text { bureaucratic needs from the } \\
\text { last Century. }\end{array}$ & $\begin{array}{l}\text { Graham, Marco, } \\
\text { and Miller 2015; } \\
\text { Franzoni and } \\
\text { Scellato } 2010\end{array}$ \\
\hline $\begin{array}{l}\text { Trade secret } \\
\text { legislation borders to } \\
\text { laws on business } \\
\text { conduct, } \\
\text { whistleblowing, and } \\
\text { privacy. }\end{array}$ & No & $\begin{array}{l}\text { In China, trade secret law is } \\
\text { based on business conduct } \\
\text { law. Privacy (e.g., in } \\
\text { medical records) is not a } \\
\text { trade secret but could be in } \\
\text { the case of biobanks. }\end{array}$ & $\begin{array}{l}\text { Caenegem 2014; } \\
\text { Lippoldt and } \\
\text { Schultz 2014; } \\
\text { Conley et al. } \\
2012\end{array}$ \\
\hline
\end{tabular}

\begin{tabular}{|c|c|c|c|}
\hline $\begin{array}{l}\text { A trade secret has a } \\
\text { value. It has an } \\
\text { impact on accounting } \\
\text { and taxation. }\end{array}$ & No & $\begin{array}{l}\text { The value of a trade secret } \\
\text { can be estimated in a } \\
\text { similar way as for patents } \\
\text { (e.g., from the net present } \\
\text { value of a royalty stream or } \\
\text { the cost to develop a } \\
\text { similar product or service or } \\
\text { misappropriate the } \\
\text { competitor's trade secret). }\end{array}$ & $\begin{array}{l}\text { Fischer and } \\
\text { Leidinger 2014; } \\
\text { Lagrost et al. } \\
2010\end{array}$ \\
\hline
\end{tabular}

11 The 18 month publication of patent applications came from the needs of the Dutch Patent Office in the 1960s. Patents were published at grant and the Dutch Patent Office had a huge backlog. No one outside the Patent Office but the applicant knew that a technology would be patented. This secrecy could last for many years, thus, wrongful investments could be made by third parties. The Dutch then began to publish all applications after 18 months of secrecy. The West-Germans followed, and then the rest of the world (see Davidson 1969; Hoffmann 1972). 


\begin{tabular}{|c|c|c|c|}
\hline ISSUES & CI & COMMENTS, EXAMPLES & REFERENCE \\
\hline $\begin{array}{l}\text { Trade secret } \\
\text { management } \\
\text { depends on } \\
\text { recording metadata } \\
\text { for trade secrets. } \\
\text { The metadata can } \\
\text { be public. }\end{array}$ & Yes & $\begin{array}{l}\text { A secret starts as concealed } \\
\text { information. The metadata } \\
\text { (e.g., the field of } \\
\text { technology or commerce, } \\
\text { the ones in the know, the } \\
\text { importance, the associated } \\
\text { IP) of the secret and its } \\
\text { concealment may be shared } \\
\text { without divulging the } \\
\text { secret. Thus, the manager } \\
\text { of trade secrets does not } \\
\text { need to know the secrets. }\end{array}$ & Li and Tsai 2009 \\
\hline $\begin{array}{l}\text { Workforce mobility } \\
\text { causes conflicts on } \\
\text { trade secrets. }\end{array}$ & No & $\begin{array}{l}\text { Employees know trade } \\
\text { secrets and bring them to a } \\
\text { new employer. It is difficult } \\
\text { not to disclose a secret in } \\
\text { the long run. Some also } \\
\text { disclose secrets out of } \\
\text { anger with the previous } \\
\text { employer, by negligence, or } \\
\text { by solicitation of the new } \\
\text { employer. The society } \\
\text { wants workforce mobility to } \\
\text { encourage knowledge flow } \\
\text { and improve the efficiency } \\
\text { of the market. }\end{array}$ & $\begin{array}{l}\text { Delerue and } \\
\text { Lejeune } 2010\end{array}$ \\
\hline
\end{tabular}




\begin{tabular}{|c|c|c|c|}
\hline ISSUES & CI & COMMENTS, EXAMPLES & REFERENCE \\
\hline $\begin{array}{l}\text { Trade secrets can be } \\
\text { used for sharing and } \\
\text { exchanging } \\
\text { knowledge, and as } \\
\text { part of open } \\
\text { innovation. }\end{array}$ & Yes & $\begin{array}{l}\text { When firms license } \\
\text { technology, the associated } \\
\text { knowledge is often in the } \\
\text { form of trade secrets. An } \\
\text { argument against secrecy is } \\
\text { that it is normatively } \\
\text { wrong, as all secrecy } \\
\text { hinders knowledge flow. } \\
\text { There is no paradox in } \\
\text { trade secrets used in open } \\
\text { innovation, as "open" does } \\
\text { not mean "published." For } \\
\text { open-source secrets, norms } \\
\text { are collaborative } \\
\text { development and shared } \\
\text { rights-and thus are not } \\
\text { trade secrets when } \\
\text { published. During } \\
\text { development, however, } \\
\text { keeping a trade secret is } \\
\text { possible. }\end{array}$ & $\begin{array}{l}\text { Empirical: } \\
\text { Lippoldt and } \\
\text { Schultz 2014 } \\
\text { Metastudy: } \\
\text { Perkmann et al. } \\
2013 \\
\text { Normative: } \\
\text { Merton 1973; } \\
\text { West and } \\
\text { Gallagher } 2006\end{array}$ \\
\hline $\begin{array}{l}\text { Trade secrets cannot } \\
\text { be managed like other } \\
\text { IP, as the property is } \\
\text { lost if published; } \\
\text { however, trade } \\
\text { secrets are mixed and } \\
\text { managed with another } \\
\text { IP. }\end{array}$ & Yes & $\begin{array}{l}\text { That property can be lost } \\
\text { by disclosure is } \\
\text { counterintuitive, and one of } \\
\text { the reasons why } \\
\text { jurisprudence struggles } \\
\text { with including trade secrets } \\
\text { as IP. Trade secrets require } \\
\text { different management; } \\
\text { however, they are managed } \\
\text { as an integrated part of IP. } \\
\text { The effect is that IP } \\
\text { management must be } \\
\text { based on that of secrecy. }\end{array}$ & $\begin{array}{l}\text { Hall et al. 2014; } \\
\text { Hurmelinna- } \\
\text { Laukkanen and } \\
\text { Puumalainen } \\
2007 ; \text { these do } \\
\text { not conclude on } \\
\text { the management } \\
\text { issues }\end{array}$ \\
\hline
\end{tabular}




\section{COMMENTS, EXAMPLES}

\section{ISSUES}

Unlike most other IP, secrecy and openness

are not solely legal concepts. They are formed in a process, and there is no rigid dichotomy.

\section{CI}

Yes

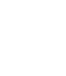

\section{COMMENTS, EXAMPLES}

Most other IP types are defined by law, but secrecy may exist and be used in trade without any involvement of law. The transition from a secret to a trade secret is a process that involves risk reduction and documentation of metadata.

The terms of a nondisclosure agreement (NDA) must be managed.

\section{No}
NDAs are complicated by specific terms that must be followed. Their purpose may depend on the legal system of the jurisdiction (e.g., differences between common and civil law).

REFERENCE

Bok 1989;

Hannah et al. 2019
Wetter et al. 2017
As for copyright, circumstances must be compared with the legal definition by a court of law. The scope of the law is set to balance copying with incentives for innovation and use of the patent system. An example is whether there were proper measures against disclosure or not.

\begin{tabular}{|c|c|c|c|}
\hline $\begin{array}{l}\text { Trade secret } \\
\text { management includes } \\
\text { cybersecurity. }\end{array}$ & No & $\begin{array}{l}\text { Both the technology of the } \\
\text { IT platform and the users } \\
\text { may have weaknesses that } \\
\text { lead to the loss of trade } \\
\text { secrets. Corporate } \\
\text { espionage is commonplace. } \\
\text { Cybercriminals are only } \\
\text { interested in trade secrets } \\
\text { (i.e., not public, have } \\
\text { value). }\end{array}$ & $\begin{array}{l}\text { Lezzi, Lazoi, and } \\
\text { Corallo 2018; } \\
\text { Villasenor 2015; } \\
\text { Rowe } 2016\end{array}$ \\
\hline
\end{tabular}




\begin{tabular}{|c|c|c|c|}
\hline ISSUES & CI & COMMENTS, EXAMPLES & REFERENCE \\
\hline $\begin{array}{l}\text { There is confidential } \\
\text { information that is not } \\
\text { trade secrets. }\end{array}$ & No & $\begin{array}{l}\text { Make Venn diagrams of } \\
\text { different terms. Privacy } \\
\text { issues and employee } \\
\text { records are typical } \\
\text { examples. }\end{array}$ & $\begin{array}{l}\text { Bok 1989; Marx } \\
\text { 2016; Weinberg } \\
\text { et al. } 2015\end{array}$ \\
\hline $\begin{array}{l}\text { Negative knowledge } \\
\text { (negative know-how) } \\
\text { can be a trade secret. }\end{array}$ & Maybe & $\begin{array}{l}\text { If a firm performs } 1000 \\
\text { experiments that fail, and } \\
\text { one that works, an } \\
\text { employee leaving for a new } \\
\text { workplace cannot use the } \\
\text { basis of the } 1000 \text { failed } \\
\text { experiments to find another } \\
\text { workable solution. If } \\
\text { explained as "negative } \\
\text { knowledge" only, it sounds } \\
\text { counterintuitive. If the view } \\
\text { is the "sweat of the brow"- } \\
\text { performed work-it is easier } \\
\text { and likely why a database is } \\
\text { protected in the United } \\
\text { States. }\end{array}$ & $\begin{array}{l}\text { Castellaneta, } \\
\text { Conti, and } \\
\text { Kacperczyk 2017; } \\
\text { Junge } 2016\end{array}$ \\
\hline
\end{tabular}

\begin{tabular}{|c|c|c|c|}
\hline $\begin{array}{l}\text { An organization can } \\
\text { have procedures for } \\
\text { handling secrecy that } \\
\text { are set by } \\
\text { management, or that } \\
\text { employees create } \\
\text { without management }\end{array}$ & No & $\begin{array}{l}\text { Given organizational } \\
\text { psychology and how } \\
\text { psychological contracts } \\
\text { develop, it is not surprising } \\
\text { and easy to explain that } \\
\text { rules develop among } \\
\text { groups of employees. }\end{array}$ & $\begin{array}{l}\text { Hannah et al. } \\
\text { 2019; Sverdrup } \\
\text { and Schei } 2015\end{array}$ \\
\hline
\end{tabular}

Table 2. Examples of challenging issues with an indication of counterintuition (the CI column).

\section{Applying Threshold Concepts}

As illustrated above, the nature of trade secrets seen from teaching and learning perspectives represents to learners and novices in the discipline 
a fluid and less distinct landscape. Also, among academics, there is a limited or unclear agreement regarding what graduates should know. There is a lack of bright points of navigation, clear or predefined goals for learners, clear ontologies, and fixed epistemologies. In sum, the teaching of trade secret management is quite challenging.

More so than in many other epistemological fields, the understanding of trade secrets and their management are dependent on developing a way of thinking and sense of understanding of "the underlying game" or "episteme"; that is, they are dependent on developing "habits of the mind" (Perkins 2006; Shulman 2005). ${ }^{12}$ Note that there is an internal relationship and interdependency among them. For example, a threshold concept, such as "trade secrets can be used in open innovation" (see Table 3 below), will at the same time be transformative and discursive, since a new perspective of reading the world will include a new way of describing what you see, in other words, an ontological shift. Table 3 shows the four issues we find counterintuitive when teaching. For these, we have briefly commented on the characteristics of threshold concepts from Table 1.

ISSUES

MAIN THRESHOLD CONCEPTS: CHARACTERISTICS AND COMMENTS

12 Habits of the mind are skills in using theory, unlike those of the heart or hand (Shulman 2005). 
ISSUES

Trade secret management depends on recording metadata for trade secrets. The metadata can be public.

Trade secrets can be used for sharing and exchanging knowledge, and as part of open innovation.

Trade secrets cannot be managed as other IP, as the property is lost if published; however, they are mixed and managed with another IP.

Secrecy and openness are not only legal concepts, as is most other IP. They are formed in a process, and there is no rigid dichotomy.
MAIN THRESHOLD CONCEPTS: CHARACTERISTICS AND COMMENTS

Transformative: Trade secrets can be part of an IP portfolio and discussed with others who are not in the know, including IP managers.

Troublesome: It is counterintuitive that the attributes of the secret are themselves not secret. Irreversible: A trade secret has attributes and metadata.

Integrative: It is the fundament for appropriating knowledge with a mix of IP that includes trade secrets.

Transformative: Trade secrets are part of the knowledge flow between firms.

Troublesome: There is no contradiction between open innovation and trade secrets.

Discursive: Changes the view of licensing.

Reconstitutive: The starting point for questioning academic and industrial norms. Also, to see how secrecy and openness balance.

Transformative: Changes the view of the early phase of innovation projects.

Troublesome: The other types of IP changes, when trade secrets are an integral part of their cycle.

Integrative: The different types of IP are integrated by trade secret initiation.

Liminality: The details of a national and international patent, copyright, trademark, and design law, as well as marketing law, must be known before trade secrets can be mixed and managed.

Transformative: The literature mostly presents trade secret management as legal management.

Troublesome: Opposed to registered IP and copyright, successful management of secrecy depends on human factors. Openness may lead to a need for secrecy, for example, in the case of biobanks and privacy issues.

Integrative: The early-stage innovation process comprises decisions on the joint use of different types of IP.

Discursive: The ability to switch between a perspective of openness and secrecy, and legal and organization concepts.

Table 3. Challenging issues compared to threshold concepts characteristics. 
In Table 3, the four issues have at least four of the eight characteristics of threshold concepts. All include the counterintuition of the "troublesome" characteristics and are also transformative. For teaching trade secret management, we then have essential issues that we find change how students view the discipline. A problem will then be to formulate these issues as learning objectives, together with other, non-troublesome issues. We discuss this aspect of curriculum later in this article.

Many learners tend to perceive their learning trajectory in the same way - as a relatively linear and directed path to mastery. The characteristics of simultaneities and counterintuitive aspects imply, from the student's perspective, a lack of clarity as to learning objectives - the precise goals or aims to be learned. This places the learner in a state of liminality (Land, Rattray, and Vivian 2014; Turner 1969; Gennep 1960). Liminality, a term derived from social anthropology, describes the period of leaving one kind of state or understanding, yet where the learner has not yet arrived in a new state or reached new understanding. This state is characterized by learner uncertainty and ambiguity, and it is up to the individual (in the anthropological sense) to move out of it. In this case, this implies replacing an understanding based on binaries with one based on simultaneities. In the understanding and management of trade secrets, liminality - or uncertainty- 
should be perceived as a space for sharing, a space of affordances and opportunities.

\section{The Epistemological Landscape}

In the previous section of this article, we described how the teaching of trade secrets is an ambiguous and complex discipline, and how the threshold concepts framework may be used as a lens through which to describe and analyze. To further explore this area, we now turn to how it should be understood in epistemological terms.

Describing a knowledge domain, and how it can be taught and learned, requires an understanding of its epistemological characteristics. Learners, even at the master level, tend to want simple ontologies, fixed epistemologies, and recipes as to how to achieve desired learning outcomes. This attitude is reinforced by current examination systems. However, to be a participant in a given field, teachers and learners need to develop an expanded understanding of what constitutes knowledge in their particular field. We draw upon three sources of epistemological framing: Polanyi's (1966) ideas of "tacit knowledge," Gibbons's (1994) distinction between "Mode 1" and "Mode 2" knowledge, and Schön's $(1987,1983)$ seminal work describing the reflective practitioner.

The knowledge perspective adopted to frame trade secrets and the teaching thereof rests on what Gibbons has termed Mode 2 knowledge 
(Gibbons 1994). Gibbons distinguish between Mode 1 and Mode 2 knowledge development: whereas Mode 1 represents traditional knowledge, reflecting the classic academic hierarchies, Mode 2 knowledge is developed in an interaction between different actors from science and industry. Typically, this kind of knowledge is developed out of a defined problem or a given context, often a "wicked" one. Consequently, this knowledge perspective is interdisciplinary and relies on both theoretical and practical input.

Furthermore, tacit knowledge plays an important part. Tacit knowledge in an organization rests in the experiences, relations, and networks among a group of people. This kind of knowledge is rarely documented or otherwise formalized but can be activated and shared when the need arises. It is consequently hard to get access to for newcomers in an organization, but the participation in communities socializes members toward a certain way of thinking. Thus, tacit knowledge is not easily taught or acquired and may emerge through dialogue, narratives, and participation. Mode 2 knowledge is more connected to its immediate application and the interplay between development and application. In a real sense, learning, also seen as an organizational endeavor, is not separate from the development of knowledge and its application. Although individual and social aspects are present in all types of learning and knowledge production, for Gibbons the individual drive is seen as dominant in Mode 1 knowledge production, and the social or collective drive is seen as dominant in Mode 2 knowledge production 
(Gibbons 1994). To learners and practitioners alike, the process of achieving knowledge in the present domain is associated with the state of liminality, recognizing emergent ontologies and epistemologies, and developing a sensitivity to context and situation. In earlier work, Schön (1987) has elaborated on these abilities of the practitioner and describes the development of such emergent knowledge as a "reflective conversation with the materials of a situation" (14), aligned with elements of improvisation and moving in "indeterminate, swampy zones of practice" (3).

\section{Trade Secret Management: An Example Curriculum}

In Table 4, we present an example curriculum building on Land et al. (2005) and Hunkins and Hammill (1994). We have placed the four threshold concepts that we identified, within a teaching progression, from the legal definitions of trade secrets to organizational improvements. An alternative way of presenting the curriculum could be to start by introducing secrecy as a human and organizational concept; the threshold concepts would then follow. This approach could be better suited to skilled IP managers. In the case of students, we find that they often lack an understanding of IP, thus legal definitions and practical examples are needed before threshold concepts can be meaningful. In a course on trade secrets for IP managers, an objective is to rapidly change their perception of trade secrets and how to manage them. Their starting point is that they know IP and thus also trade 
secrets, yet they do not have much time to devote to the course. Early introduction of discipline-specific threshold concepts can then incite their learning of the details. For students in a master's-level course, the general concepts of IP can be taught together with trade secret management. The pace would most likely be slower, and there would thus be more time for reflection.

Topic

Motivation

Definition of trade secrets

Practical examples of the definition

Examples of practice areas where trade secrets differ from other IP

\section{Threshold concept: Metadata}

Trade secrets are a subset of confidential information

\section{Content}

Changes - legal, tax, employee mobility, cloud computing, cybercriminals, open innovation, trade wars, secrecy as part of human nature, differences in attitude in academia and industry.

The legal definition in the EU and European countries, the USA, China, and Japan. There are many sources from preparation of the new legislation.

What is "not public"? How much value must the secret have? What measures must be taken? What are the exemptions, and the ethical and societal considerations?

Both technical and commercial information; no registration, no fees, it cannot be published; the secret need not be static-it can change; no time limits, no requirements for documentation.

Starting to explain metadata and how it can be used to delimit and document the secret. Use examples, let the students fill in metadata. Discuss how the metadata may be public.

Using privacy and personnel records as an example. 
Topic
Compare patents and trade
secrets

Compare copyright and trade secrets

Famous examplesdiscussion

Exploring examples

\section{Threshold concept: Trade secrets managed differently but mixed with other IP}

Licensing needs an object to license

\section{Threshold concept: Trade secrets in knowledge exchange, and as part of open innovation}

Introduce the valuation of trade secrets

Introduce the role of the employee and the procedures in an organization

\section{Threshold concept:} It is not only the legal definition that matters but keeping the information confidential and staying out of courts; there is no dichotomy but a process

Cybercriminals only interested in trade secrets, not other IP

\section{Content}

Examples, on patent applications being secret and prior use rights.

Examples, on software, open-source and database rights.

For example, are Coca Cola and WD40 formulas trade secrets?

Employee mobility and cybercrime.

Negative information, inventions that cannot be patented, big data, client data.

Using recent litigation as cases.

Building on the discussions and examples. Use research collaborations as an example: Secrecy must be secured from the beginning if it is needed in the commercialization of technology. It may be needed as an object for licensing.

Discuss trade secrets in licensing and how it is combined with other IP.

Lift the discussion to open innovation and knowledge flow in society, and how trade secret legislation facilitates that; then use licensing as practical examples. Show agreements.

The value must be understood when licensing and exchanging information. Discuss accounting standards and tax issues.

Discuss how confidentiality is handled (trade secrets and, e.g., privacy) - coming back to trade secrets being a subset.

Using the role of employee and project teams to move to organizational issues. If secrets are successfully kept, there is no need to distinguish between their variants. The secrets are flexible over time. Documentation is risk management.

Other IP is usually public, so protection is from the legal system 


Topic
The roles of individuals,
teams, organizations, and
states
Introduce steps to improve
the organization

\section{Content}

Secrecy as a natural part of work life. Lifting the discussion to procedures and innovation systems. Coming back to exemptions, ethics, and flow of knowledge in society.

Education, governance and policy, processes in place, IP portfolio management, including trade secrets with metadata.

Table 4. An example curriculum with threshold concepts.

\section{Conclusion}

We have demonstrated that four central issues in the teaching of trade secret management can be viewed through the lens of threshold concepts, and thus be used to open the field to learners. We then showed how these concepts might be used in an example curriculum. In theorizing on this topic, we link the lack of ontological clarity to the simultaneities, and to how trade secret management integrates with IP management. We relate this understanding to the epistemological concepts of tacit knowledge, Mode 2 knowledge, and the reflective practitioner.

We explained IP management and trade secret management as a practitioners' skill to provide an example curriculum aimed at the education of management practitioners. However, this contribution is not only related to management and educational sciences, but also has relevance to innovation studies and jurisprudence. Trade secrets are part of the broader concept of appropriation mechanisms. For researchers of innovation and jurisprudence, it is crucial to understand better the ontological shift from 
trade secrets for keeping knowledge secluded to trade secrets used for knowledge transfer in open innovation. There is then no dichotomy of openness and secrecy, but a process of knowledge appropriation in which well-defined trade secrets blend with other appropriation mechanisms that include intellectual property.

\section{Limitations and Future Research}

The present study is conceptual. We build our proposals for using threshold concepts in trade secret management education on limited experience. Two of the authors have long experience in teaching IP management, but mainly in the Nordic countries and the United Kingdom; we know from the literature that there are cultural differences in how secrecy is used for innovation (Delerue and Lejeune 2011; Serradell-Lopez and Cavaller 2009). As discussed earlier in this article, there are also legal differences. With the new EU and US legislation, regions have moved toward viewing trade secrets more as property than, for example, Japanese and Chinese legislation, which sees the issue as a question of fair competition. These cultural differences may have an impact on what issues are considered to be counterintuitive. Thus, the impact of cultural differences on the teaching of trade secret management is an exciting possibility for future research. 
In our experience, there seems to be a male bias in the attendance of both academic and industrial courses on IP management. Delerue and Hamid (2015) find no gender differences in the ethical attitude to trade secret misappropriation. However, there are reported gender differences in the attitude to secrecy among adolescents (Frijns et al. 2005). These studies may be a starting point for research on gender differences relevant to the teaching of trade secret management.

In Table 2, we referred to literature on the issue of trade secrets in open innovation. There are differences in the approach to trade secrets among fields of industry, as well as among academic institutions and firms. One example from the ICT industry, reported by Feldman (2006), empirically examined whether trade secret law affects high-tech employees' willingness to keep information confidential. In a study of the life sciences field, researchers who cooperated with industry expectedly reported more trade secret results from their research (Blumenthal et al. 1996). The effects of industrial sponsorship on researchers are discussed by Czarnitzki, Grimpe, and Pellens (2015). We have not tested the four threshold concepts we identify in courses for differences in learning outcomes versus the industrial or academic background of the learners (Flanagan et al. 2014). To identify such differences would be an interesting question for further research.

We started our discussion on trade secrets by pointing at the lack of ontological clarity, then explored the epistemological landscape and 
connected it to the discussion on Mode 2 knowledge. When knowledge production is collaborative, the management of trade secrets must adapt. This is clearly another area for future research (Ankrah and Al-Tabbaa 2015). As the management of trade secrets develops, so must the teaching also develop and evolve. Our hope is that the framework of threshold concepts may improve upon the teaching of trade secret management.

\section{Acknowledgements}

The authors thank the Center for Intellectual Property (CIP) and NORSI - the Norwegian Research School in Innovation for discussions, professors Ulf Petrusson and Roger Sørheim for the research project supervision, Knut Jørgen Egelie and Kjersti Staven-Garberg for discussions and comments, as well as the anonymous reviewers and the editor for the many constructive suggestions.

This research was co-funded by Leogriff and the Research Council of Norway with Industrial PhD grant 247566 and by Chawton Innovation Services.

\section{References}

Abazi, Vigjilenca. 2016. "Trade Secrets and Whistleblower Protection in the European Union." European Papers 1 (3): 1061-72.

Al-Aali, Abdulrahman Y., and David J. Teece. 2013. "Towards the (Strategic) Management of Intellectual Property: Retrospective and Prospective." California Management Review 55 (4): 15-30.

Ankrah, Samuel, and Omar Al-Tabbaa. 2015. "Universities-industry Collaboration: A Systematic Review." Scandinavian Journal of Management 31 (3): 387-408. 
Arrow, Kenneth. 1962. "Economic Welfare and the Allocation of Resources for Invention." In The Rate and Direction of Inventive Activity: Economic and Social Factors, 609-26. Princeton: Princeton University Press._ http://www.nber.org/chapters/c2144

Arundel, Anthony. 2001. "The Relative Effectiveness of Patents and Secrecy for Appropriation." Research Policy 30 (4): 611-24.

Blumenthal, David, Eric G. Campbell, Nancyanne Causino, and Karen Seashore Louis. 1996. "Participation of Life-Science Faculty in Research Relationships with Industry." New England Journal of Medicine 335 (23): 1734-39.

Bodenhausen, Georg Hendrik Christiaan. 1968. Guide to the Application of the Paris Convention for the Protection of Industrial Property, as Revised at Stockholm in 1967. 611. WIPO. https://www.wipo.int/edocs/pubdocs/en/intproperty/611/wipo_pub_611 .pdf

Bogers, Marcel. 2011. "The Open Innovation Paradox: Knowledge Sharing and Protection in R\&D Collaborations." European Journal of Innovation Management 14 (1): 93-117.

Bok, Sissela. 1989. Secrets: On the Ethics of Concealment and Revelation. New York: Vintage.

Bos, Brenda, Thijs L. J. Broekhuizen, and Pedro de Faria. 2015. "A Dynamic View on Secrecy Management." Journal of Business Research 68 (12): 2619-27.

Burgess, Christopher, and Richard Power. 2011. Secrets Stolen, Fortunes Lost: Preventing Intellectual Property Theft and Economic Espionage in the 21st Century. London: Syngress.

Caenegem, William van. 2014. Trade Secrets and Intellectual Property: Breach of Confidence, Misappropriation and Unfair Competition. Alphen aan den Rijn, Netherlands: Wolters Kluwer.

Castellaneta, Francesco, Raffaele Conti, and Aleksandra Kacperczyk. 2017. "Money Secrets: How Does Trade Secret Legal Protection Affect Firm Market Value? Evidence from the Uniform Trade Secret Act." Strategic Management Journal 38 (4): 834-53. 
Cohen, Wesley M., Richard R. Nelson, and John P. Walsh. 2000. Protecting Their Intellectual Assets: Appropriability Conditions and Why US Manufacturing Firms Patent (or Not). National Bureau of Economic Research. https://www.nber.org/papers/w7552.pdf

Conley, John M., Robert Mitchell, R. Jean Cadigan, Arlene M. Davis, Allison W. Dobson, and Ryan Q. Gladden. 2012. "A Trade Secret Model for Genomic Biobanking." The Journal of Law, Medicine \& Ethics: A Journal of the American Society of Law, Medicine \& Ethics 40 (3): 612-29.

Cook-Deegan, Robert, John M. Conley, James P. Evans, and Daniel Vorhaus. 2012. "The Next Controversy in Genetic Testing: Clinical Data As Trade Secrets?" European Journal of Human Genetics 21:585.

Costas, Jana, and Christopher Grey. 2014. "Bringing Secrecy into the Open: Towards a Theorization of the Social Processes of Organizational Secrecy." Organization Studies 35 (10): 1423-47.

Cousin, Glynis. 2006. "An Introduction to Threshold Concepts." Planet 17 (1): 4-5.

Crittenden, William F., Victoria L. Crittenden, and Allison Pierpont. 2015. "Trade Secrets: Managerial Guidance for Competitive Advantage." Business Horizons 58 (6): 607-13.

Czarnitzki, Dirk, Christoph Grimpe, and Maikel Pellens. 2015. "Access to Research Inputs: Open Science Versus the Entrepreneurial University." The Journal of Technology Transfer 40 (6): 1050-63.

Davis, Brent. 2008. "Complexity and Education: Vital Simultaneities." Educational Philosophy and Theory 40 (1): 50-65.

Davidson, Cornelis Marinus Reinder. 1969. "The Experience in Holland in Respect of Deferred Examination of Patent Applications." Nordiskt Immateriellt Rättsskydd (2): 156-64.

Delerue, Hélène, and Mariam Hamid. 2015. "Who Are These People? Personality Traits and Judgments about Trade Secret Misappropriation in Post-employment Activities." Business Ethics 24 (3): 315-31.

Delerue, Hélène, and Albert Lejeune. 2010. "Job Mobility Restriction Mechanisms and Appropriability in Organizations: The Mediating Role of Secrecy and Lead Time." Technovation 30 (5-6): 359-66. 
. 2011. "Managerial Secrecy and Intellectual Asset Protection in SMEs: The Role of Institutional Environment." Journal of International Management 17:130-42.

European Commission. 2016. Directive of the European Parliament and of the Council On the Protection of Undisclosed Know-How and Business Information (Trade Secrets) Against Their Unlawful Acquisition, Use and Disclosure. Brussels. https://eur-lex.europa.eu/legalcontent/EN/TXT/?uri=CELEX\%3A32016L0943

Eurostat. 2016. Methods for Maintaining or Increasing the Competitiveness in the Enterprises-As Highly Important and Not Used by NACE Rev. 2 Activity and Size Class. Eurostat. http://appsso.eurostat.ec.europa.eu/nui/show.do

Evans, Michelle. 2012. "Trade Secrets in the Legal Studies Curriculum-A Case Study." Journal of Legal Studies Education 29 (1): 1-25.

Feldman, Yuval. 2006. "The Behavioral Foundations of Trade Secrets: Tangibility, Authorship, and Legality." Journal of Empirical Legal Studies 3 (2): 197-235.

Fischer, Timo, and Jan Leidinger. 2014. "Testing Patent Value Indicators on Directly Observed Patent Value-An Empirical Analysis of Ocean Tomo Patent Auctions." Research Policy 43 (3): 519-29.

Flanagan, Michael T. 2020. "Threshold Concepts: Undergraduate Teaching, Postgraduate Training, Professional Development and School Education. A Short Introduction and a Bibliography from 2003 to 2018." https://www.ee.ucl.ac.uk/ mflanaga/thresholds.html

Flanagan, Michael T., Gerhard Ackermann, Matthias Zimmermann, Leif Martin Hokstad, Bjørn Andersen, and Manuel Fradinho. 2014. A Comparative Academic/Industrial Professional Development Study in Project Management in Threshold Concepts: From Personal Practice to Communities of Practice. National Academy's Sixth Annual Conference and the Fourth Biennial Threshold Concepts Conference, Dublin, Ireland. https://eric.ed.gov/?id=ED558533

Franzoni, Chiara, and Giuseppe Scellato. 2010. "The Grace Period in International Patent Law and Its Effect on the Timing of Disclosure." Research Policy 39 (2): 200-13. 
Frijns, Tom, Catrin Finkenauer, Ad A. Vermulst, and Rutger C.M.E. Engels. 2005. "Keeping Secrets from Parents: Longitudinal Associations of Secrecy in Adolescence." Journal of Youth and Adolescence 34 (2): 13748.

Gallié, Emilie-Pauline, and Diégo Legros. 2012. "French Firms' Strategies for Protecting Their Intellectual Property." Research Policy 41 (4): 78094.

Gennep, Arnold van. 1960. The Rites of Passage. Les Rites de Passage. London: Routledge \& Kegan Paul.

Gibbons, Michael. 1994. The New Production of Knowledge: The Dynamics of Science and Research in Contemporary Societies. London: Sage.

Graham, Stuart J. H., Alan Marco, and Richard Miller. 2015. The USPTO Patent Examination Research Dataset: A Window on the Process of Patent Examination.

https://www.uspto.gov/sites/default/files/documents/PatEx\%20Working \%20Paper.pdf

Granstrand, Ove. 2000. "Corporate Management of Intellectual Property in Japan." International Journal of Technology Management 19 (1-2): 12148.

Grey, Christopher, and Jana Costas. 2016. Secrecy at Work: The Hidden Architecture of Organizational Life. Stanford, CA: Stanford University Press.

Hall, Bronwyn, Christian Helmers, Mark Rogers, and Vania Sena. 2014. "The Choice between Formal and Informal Intellectual Property: A Review." Journal of Economic Literature 52 (2): 375-423.

Hannah, David. 2005. "Should I Keep a Secret? The Effects of Trade Secret Protection Procedures on Employees' Obligations to Protect Trade Secrets." Organization Science 16 (1): 71-84.

Hannah, David, Michael Parent, Leyland Pitt, and Pierre Berthon. 2019. "Secrets and Knowledge Management Strategy: The Role of Secrecy Appropriation Mechanisms in Realizing Value from Firm Innovations." Journal of Knowledge Management 23 (2): 297-312. 
Hannah, David R., and Kirsten M. Robertson. 2015. "Why and How Do Employees Break and Bend Confidential Information Protection Rules?" Journal of Management Studies 52 (3): 381-413.

Hemphill, Thomas. 2004. "The Strategic Management of Trade Secrets in Technology-based Firms." Technology Analysis \& Strategic Management 16 (4): 479-94.

Hilgartner, Stephen. 2012. "Selective Flows of Knowledge in Technoscientific Interaction: Information Control in Genome Research." The British Journal for the History of Science 45 (2): 267-80.

Hoffmann, Klaus. 1972. "Three Years Experience with the Deferred Examination System in Germany." IIC-International Review of Intellectual Property and Competition Law (2): 164-83.

Holgersson, Marcus, and Martin W. Wallin. 2017. "The Patent Management Trichotomy: Patenting, Publishing, and Secrecy." Management Decision 55 (6): 1087-99.

Hunkins, Francis P., and Patricia A. Hammill. 1994. "Beyond Tyler and Taba: Reconceptualizing the Curriculum Process." Peabody Journal of Education 69 (3): 4-18.

Hurmelinna-Laukkanen, Pia, and Kaisu Puumalainen. 2007. "Nature and Dynamics of Appropriability: Strategies for Appropriating Returns on Innovation." R\&D Management 37 (2): 95-112.

Junge, Fabian. 2016. "The Necessity of European Harmonization in the Area of Trade Secrets." Working Paper No. 2016/04. Maastricht European Private Law Institute, Maastricht University, Netherlands.

Lagrost, Céline, Donald Martin, Cyrille Dubois, and Serge Quazzotti. 2010. "Intellectual Property Valuation: How to Approach the Selection of an Appropriate Valuation Method." Journal of Intellectual Capital 11 (4): 481-503.

Land, Ray, Glynis Cousin, Jan H. F. Meyer, and Peter Davies. 2005. "Threshold Concepts and Troublesome Knowledge (3): Implications for Course Design and Evaluation." Improving Student Learning Diversity and Inclusivity 4:53-64. 
Land, Ray, Julie Rattray, and Peter Vivian. 2014. "Learning in the Liminal Space: A Semiotic Approach to Threshold Concepts." Higher Education 67 (2): 199-217.

Laursen, Keld, and Ammon J. Salter. 2014. "The Paradox of Openness: Appropriability, External Search and Collaboration." Research Policy 43 (5): 867-78.

Leiponen, Aija, and Justin Byma. 2009. "If You Cannot Block, You Better Run: Small Firms, Cooperative Innovation, and Appropriation Strategies." Research Policy 38 (9): 1478-88.

Lemley, Mark A. 2008. "The Surprising Virtues of Treating Trade Secrets as IP Rights." Stanford Law Review 61 (2): 311-53.

Levin, Richard C., Alvin K. Klevorick, Richard R. Nelson, Sidney G. Winter, Richard Gilbert, and Zvi Griliches. 1987. "Appropriating the Returns from Industrial Research and Development." Brookings Papers on Economic Activity 1987 (3): 783-831.

Levine, David S., and Christopher B. Seaman. 2018. "The DTSA at One: An Empirical Study of the First Year of Litigation under the Defend Trade Secrets Act." Wake Forest Law Review 53:105.

Lezzi, Marianna, Mariangela Lazoi, and Angelo Corallo. 2018. "Cybersecurity for Industry 4.0 in the Current Literature: A Reference Framework." Computers in Industry 103:97-110.

Li, Sheng-Tun, and Ming-Hong Tsai. 2009. "A Dynamic Taxonomy for Managing Knowledge Assets." Technovation 29 (4): 284-98.

Lippoldt, Douglas C., and Mark F. Schultz. 2014. Uncovering Trade Secrets-An Empirical Assessment of Economic Implications of Protection for Undisclosed Data. OECD Trade Policy Paper No. 162. https://doi.org/10.1787/5jxzl5w3j3s6-en

Maret, Susan. 2016. "The Charm of Secrecy: Secrecy and Society as Secrecy Studies." Secrecy and Society 1 (1): 1.

Marx, Gary T. 2016. "Humpty Dumpty Was Wrong-Consistency in Meaning Matters: Some Definitions of Privacy, Publicity, Secrecy, and Other Family Members." Secrecy and Society 1 (1): 3.

Marx, Gary T., and Glenn W. Muschert. 2009. "Simmel on Secrecy: A Legacy and Inheritance for the Sociology of Information." In Soziologie als 
Möglichkeit: 100 Jahre Georg Simmels Untersuchungen über die Formen der Vergesellschaftung, edited by Cécile Rol and Christian Papilloud, 217-33. Wiesbaden, Germany: VS Verlag für Sozialwissenschaften. http://web.mit.edu/gtmarx/www/marx-muschert-simmel.pdf

Menell, Peter S. 2017. "Tailoring a Public Policy Exception to Trade Secret Protection." California Law Review 105:1.

Merton, Robert K. 1973. The Sociology of Science: Theoretical and Empirical Investigations. Chicago: University of Chicago Press.

Meyer, Jan H. F., and Ray Land. 2003. Threshold Concepts and Troublesome Knowledge: Linkages to Ways of Thinking and Practising within the Disciplines. Edinburgh: University of Edinburgh.

. 2005. "Threshold Concepts and Troublesome Knowledge (2): Epistemological Considerations and a Conceptual Framework for Teaching and Learning." Higher Education 49 (3): 373-88.

. 2006. "Threshold concepts and troublesome knowledge: An introduction." In Overcoming Barriers to Student Understanding: Threshold Concepts and Troublesome Knowledge, edited by Jan H. F. Meyer and Ray Land, 3-18. Abingdon, UK: Routledge.

Middendorf, Joan, and David Pace. 2004. "Decoding the Disciplines: A Model for Helping Students Learn Disciplinary Ways of Thinking." New Directions for Teaching and Learning 2004 (98): 1-12.

Nicola-Richmond, Kelli, Geneviève Pépin, Helen Larkin, and Charlotte TayIor. 2018. "Threshold Concepts in Higher Education: A Synthesis of the Literature Relating to Measurement of Threshold Crossing." Higher Education Research \& Development 37 (1): 101-14.

Nonaka, Ikujiro, and David J Teece. 2001. Managing Industrial Knowledge: Creation, Transfer and Utilization: 3-4, 332. London: Sage.

Ottoz, Elisabetta, and Franco Cugno. 2011. "Choosing the Scope of Trade Secret Law When Secrets Complement Patents." International Review of Law and Economics 31 (4): 219-27.

Perkins, David. 2006. "Constructivism and troublesome knowledge." In Overcoming barriers to student Understanding: Threshold Concepts and Troublesome Knowledge, edited by Jan H. F. Meyer and Ray Land, 3347. Abingdon, UK: Routledge. 
Polanyi, Michael. 1966. "The Logic of Tacit Inference." Philosophy 41 (155): 1-18.

Right2INFO.org. 2019. Commercial Secrets Exemption. https://www.right2info.org/exceptions-to-access/commercial-secrets

Robertson, Kirsten M., David R. Hannah, and Brenda A. Lautsch. 2015. "The Secret to Protecting Trade Secrets: How to Create Positive Secrecy Climates in Organizations." Business Horizons 58 (6): 669-77.

Robinson, John. 2003. "Future Subjunctive: Backcasting as Social Learning." Futures 35 (8): 839-56.

Rowe, Elizabeth A. 2016. "RATs, TRAPs, and Trade Secrets." Boston College Law Review 57 (2): 381.

Sandeen, Sharon K. 2018. "Out of Thin Air: Trade Secrets, Cybersecurity, and the Wrongful Acquisition Tort." Minnesota Journal of Law Science \& Technology 19:373.

Sandeen, Sharon K., and Christopher B. Seaman. 2017. "Toward a Federal Jurisprudence of Trade Secret Law." Berkeley Technology Law Journal 32:829.

Schön, Donald A. 1983. The Reflective Practitioner: How Professionals Think in Action. London: Temple Smith. . 1987. Educating the Reflective Practitioner: Toward a New Design for Teaching and Learning in the Professions. New York: John Wiley \& Sons.

Schultz, Mark F., and Douglas C. Lippoldt. 2018. "Litigating Trade Secrets: An International Comparative Assessment of Civil and Criminal Trade Secret Enforcement." The Sedona Conference. https://thesedonaconference.org/sites/default/files/conference papers/ \%5B7.1\%5D\%20M.\%20Schultz\%20\%2B\%20D.\%20Lippoldt Litigating $\% 20$ Trade $\% 20$ Secrets $\% 20$ An $\% 20$ Int $\% 271 \% 20$ Comparative $\% 20$ Assess ment.pdf

Serradell-Lopez, Enric, and Victor Cavaller. 2009. "National Culture and the Secrecy of Innovations." International Journal of Knowledge and Learning 5 (3-4): 222-34.

Shanahan, Martin, and Jan H. F. Meyer. 2006. "The Troublesome Nature of a Threshold Concept in Economics." In Overcoming Barriers to Stu- 
dent Understanding: Threshold Concepts and Troublesome Knowledge, edited by Jan H. F. Meyer and Ray Land, 124-38. Abingdon, UK: Routledge.

Shopkow, Leah. 2010. "What Decoding the Disciplines Can Offer Threshold Concepts." In Threshold Concepts and Transformational Learning, edited by Jan H. F. Meyer, Ray Land, and Caroline Baillie, 317-31. Rotterdam, Netherlands: Brill Sense.

Shulman, Lee S. 2005. "Signature Pedagogies in the Professions." Daedalus 134 (3): 52-9.

Simmel, Georg. 1906. "The Sociology of Secrecy and of Secret Societies." American Journal of Sociology 11 (4): 441.

Sverdrup, Therese E., and Vidar Schei. 2015. "'Cut Me Some Slack": The Psychological Contracts as a Foundation for Understanding Team Charters." Journal of Applied Behavioral Science 51 (4): 451-78.

Teece, David J. 1986. "Profiting from Technological Innovation: Implications for Integration, Collaboration, Licensing and Public Policy." Research Policy 15 (6): 285-305.

. 2018. "Profiting from Innovation in the Digital Economy: Enabling Technologies, Standards, and Licensing Models in the Wireless World." Research Policy 47 (8): 1367-87.

Turner, Victor W. 1969. The Ritual Process: Structure and Anti-Structure. Chicago: Aldine.

Vermeir, Koen, and Dániel Margócsy. 2012. "States of Secrecy: An Introduction." The British Journal for the History of Science 45 (2): 153-64.

Villasenor, John. 2015. "Corporate Cybersecurity Realism: Managing Trade Secrets in a World Where Breaches Occur." AIPLA Quarterly Journal 43 $(2 / 3)$.

https://www.hoover.org/sites/default/files/corporatecybersecurityrealis $\underline{\text { m.pdf }}$

Von Hippel, Eric. 1982. "Appropriability of Innovation Benefit as a Predictor of the Source of Innovation." Research Policy 11 (2): 95-115.

Weinberg, Bruce D., George R. Milne, Yana G. Andonova, and Fatima M. Hajjat. 2015. "Internet of Things: Convenience vs. Privacy and Secrecy." Business Horizons 58 (6): 615-24. 
West, Joel, and Scott Gallagher. 2006. "Challenges of Open Innovation: The Paradox of Firm Investment in Open-source Software." R\&D Management 36 (3): 319-31.

Wetter, Olive E., Franziska Hofer, Philipp Schmutz, and Klaus Jonas. 2017. "Improving the Effectiveness of Nondisclosure Agreements by Strengthening Concept Learning." R\&D Management 47 (2): 253-64.

WIPO. 2008. WIPO Intellectual Property Handbook. No. 489 (E). Geneva: World Intellectual Property Organization. https://www.wipo.int/edocs/pubdocs/en/intproperty/489/wipo pub 489 .pdf 